\title{
PHENOLOGY OF INQUILINE AND NEST-MAKING BEES.
}

\author{
By Charles Robertson \\ Carlinville, Illinois.
}

Cases observed with a flight of only 1-10 days are excluded as fragmentary. Comparisons should be made with 6, 105-9.

Colletes and Epeolus.-Colletes flies 224 days, Mar. 20-Oct. 30, six together June 20-29 and Aug. 26-Sept. 5. It shows a maximum of 46.6 per cent June $21,53.3$ per cent flying in July and August. Epeolus flies 148 days, May 29-Oct. 23, four together Aug. 29-Sept. 5. Its flight is 76 days shorter than that of Colletes. C. incequalis lacks only 3 days of completing its flight of 81 days, Mar. 20-May 31, before Epeolus begins. Evidently it is not infested by any Epeolus.

E. interruptus, May 29-June 19, is evidently an inquiline of C. astivalis, May 8-July 1. It may, however, belong to C. brevicornis, May 29-June 29, or to both. E. bifasciatus, June 12-Oct. 3 , is probably an inquiline of $C$. latitarsis, June 13-Oct. 1, and perhaps also of $C$. willistonii, May 28-Sept. $5 ;$ E. pusillus, Aug. 26-Oct. 23, of C. americanus, Aug. 18-Oct. 30; E. autumnalis, Aug. 29-Oct. 13, of C. compactus, Aug. 26-Oct. 21. The former pair are small, the latter large. C. armatus, Aug. 17-Oct. 7 may be infested also by E. autumnalis or by E. coreopsis, Aug. 20Sept. 5 .

Grænicher (3) says Argyroselenis minimus is an inquiline of C. eulophi, which flies 146 days, May 28-Oct. 30. I have taken A. minimus but once, July 8 .

Mecaghilini and Coelioxys.-The Megachilini, 14 species, fly 165 days, May 11-Oct. 22, all together for 8 days, July 3-10. Six species of Colioxys fly 161 days, May 12-Oct. 19, all together for 42 days, July 4-Aug. 14.

Megachile brevis, May 15-Oct. 22, may be infested by $C$. octodentata, May 12-Oct. 19 (I think it has been recorded in Ent. News) and M. mendica,.May 16-Oct. 11, by $C$. sayi, May 21-Oct. 4. Xanthosarus latimanus, May 28-Oct. 20, is infested by $C$. rufitarsis, July 4-Oct. 19, according to Grænicher (2), and I have 
seen the inquiline enter the burrows. Oligotropus campanula, June 25-Sept. 14, is probably infested by $C$. modesta, June 25Aug. 28, both small species. The flight of C. texana, June 25Aug. 14, and C. germana, June 25-Sept. 3, are covered by the flight of Megachile generosa, June 11-Sept. 28, M. sexdentata, June 14-Sept. 10, and $M$. petulans, June 17-Sept. 20. According to Shuckard (7) Colioxys infests Megachilini with modified front tarsi. There are not as many inquilines as would be expected otherwise.

Osmiince and Stelidini.-The Osmiinæ fly 211 days, Mar. 21Oct. 18, with a maximum of 75 per cent June 16,90 per cent flying in June. May 21-25, 28 and June 6-11, 70 per cent are flying. The Stelidini fly 163 days, May 9-Oct. 18, all together May 7-14.

Alcidamea simplex, 85 days, May 3-July 26, and Microstelis lateralis, 43 days, May 9-June 20, are host and inquiline (Crawford 8, 5)., Neotrypetes carinatus, 144 days, May 28-Oct. 18, and productus, 138 days, June 3-Oct. 28, the females mixed and counted for both species, are evidently infested by Stelidium trypetinum, 135 days, June 6-Oct. 18. In 6, 109, productus should be carinatus.

Bombince and Psithyrus.-Bombus americanorum, Mar. 5Nov., and $P$. variabilis, Apr. 28-Nov., are host and inquiline, as stated by Frison (1). Their time and frequency indicate this. Halictida, Sphecodini and Paralictus.-The Halictidæ, Mar. 17-Nov., are probably infested by Sphecodini, Mar. 31-Nov. Chloralictus is probably host of Paralictus, both March 15-Nov. $P$. cephalicus, May 9-Oct. 19, was taken at a bank where $C$. zephyrus, Mar. 21-Nov., was nesting.

I would arrange the Halictidæ as follows: Halictinæ, wing veins not enfeebled; Halictini: Halictus, etc.; Sphecodini: Sphecodes, etc.; Lasioglossinæ, outer veins enfeebled; Lasioglossini: Curtisapis, Evylæus; Chloralictini: Chloralictus, Dialictus, Paralictus. The last is an offshoot from Chloralictus. The Sphecodini were derived from Halictini, not from the forms with outer veins enfeebled.

Andrenidœe and Nomadidœ.-The Andrenidæ fly 227 days, March 17-Oct. 30, have a maximum of 68.8 per cent May 11-13, 
75.5 per cent flying in May, 64.4 in April, 48.8 in June. Only one is flying July 30-Aug. 12, while 6 are simultaneous Sept. 8-20. The Nonadidæ fly 212 days, Mar. 21-Oct. 19. Twenty species fly 129 days, Mar. 27-July 27. The maximum is May 5 when there are 14 species flying simultaneously. Three species fly 54 days, Aug.27-Oct. 19, all together for 25 days, Sept. 8-Oct. 2.

Forty-five species of Andrenidæ and 20 of Nomadidæ complete their flight before August and are evidently related as host and inquiline, but there are so many that it is hard to match them. I think Centrias erigerontis, June 17-21, is an inquiline of Pterandrena rudbeckice, June 10-Aug. 17. C. americanus, Apr. 29 -July 16, ends when only 3 Andrenidæ are flying, Pterandrena rudbeckice, Trachandrena quintilis and T. obscura. It begins 42 days before any of these, in which time it evidently infests some other species. Cephen texanus, July 17-27, probably belongs to Trachandrena quintilis, July 8-29, T. obscura- July 16, or Pterandrena rudbeckice, which are the only Andrenidæ flying at the time. Holonomada vincta, Aug. 27-Oct. 2, is probably an inquiline of Pterandrena helianthi, Aug. 27-Oct. 10. H. placida, a small species, Sept. 6-Oct. 19, may belong to Pterandrena solidaginis, Aug. 13-Oct. 22, or Andrena nubecula, Aug. 13-Oct. 30. Nomada vicina, Sept. 8-Oct. 19, is most closely associated in time with Pterandrena asteris, Sept. 8-Oct. 21.

Panurgidœe and Pasititidœ.-Holcopasites illinonsis, June 6Aug. 23, is probably an inquiline of Calliopsis andreniformis, May 30-Oct. 14. Heterosarus parvus and Pseudopanurgus albitarsis are the only other Panurgidæ flying in the early part of June.

Anthophoridae and Melectidx.-Five species of Anthophoridæ fly 166 days, Apr. 8-Sept. 20, averaging 63.4 days. Excluding Emphoropsis floridana, the male observed for 16 days, the average is 75.2 .

Bombomelecta thoracica, April 18-May 28, flies during the time of Anthophora ursina, April 8-June 22. Melecta interrupta, taken twice, June 18, July 19, is probably an inquiline of Amegilla walshii, July 6-Sept. 20. It no doubt flies much later than Anthemoessa abrupta, May 7-July 29, and Clisoden terminalis, May 25-July 27. 
Emphorido, Eucerida and Triepeolus.-The Euceridæ fly 198 days, Apr. 8-Oct. 22. Excluding Tetralonia, they fly 132 days, June 13-Oct. 22. Triepeolus flies 118 days, June 26-Oct. 21, all together for 5 days, Aug. 30-Sept. 3.

In 4, 37, I accepted Ashmead's erroneous opinion because Triepeolus was mixed with Epeolus. There were too many of them and they were too large to be inquilines of Colletes.

Triepeolus donatus, Aug. 11-Oct. 11 infests Melitoma taurea, June 24-Oct. 7 (Ashmead in 5). T. helianthi, Aug. 11-Oct. 3, infests Melissodes trinodis, June 14-Oct. 6 (Grænicher 2). T. pectoralis, Aug. 30-Oct. 21, coincides pretty well with M. autumnalis Aug. 21-Oct. 22. Triepeolus is too late to infest Tetralonia. Tetralonia dilecta, Apr. 18-July 14, may be infested by Holonomada superba, Apr. 20-June 24.

Of 296 local species, the short-tongued bees are 50.6 per cent. In general they are the primitive bees and occupy the original positions. The long-tongued bees, developed later, have turned to flowers whose nectar has become so deeply seated as to be rather inaccessible to the short-tongues. They have not displaced the lower bees, but have taken up new ecological positions. That the long-tongues have been compelled to find new places for themselves is shown in the development of inquilines, 77.7 per cent of which are long-tongues. Inquilines are 38.3 per cent of long-tongued bees and 10.6 per cent of short-tongued bees.

Of the short-tongues, the Halictidæ are the only ones which have developed inquilines, Sphecodini and Paralictus. Natural selection seems to have favored the development of inquilines, just as if they could live at the expense of previously established bees better than they could actively compete with them.

About the only adaptive characters shown by inquilines are differences in size. They run smaller than their hosts and the small species belong to small hosts.

The characters by which the species may be distinguished are unusually non-adaptive. The mutationists, with whom the origin of species seems to be the same as the origin of specific characters, might readily point to inquilines as species with whose origin natural selection had nothing to do.

The inquilines, however, generally, if not always, have 
different hosts with which their size and flight are correlated. Natural selection clearly favors this diversification. My view is that the inquilines separated first and got their specific differences afterwards.

An inquiline producing mutants infesting the same host could not produce more individuals and could not become the basis of new evolution any more than one which did not produce them.

As regards species in general I hold that everyone has selective characteristics, holds its own bionomic position, and is the result of natural selection.

Note on Sphecodini.-According to Schuckard (7, 108), St. Fargeau, Westwood and Latreille regarded these bees as inquilines, while Kirby and Smith regarded them as nest-makers. Mueller (9, 50) says they feed their young with the disgorged surplus of their own food.

\section{Literature Cíted.}

1. Frison, T. H. 1916. Note on the habits of Psithyrus variabilis. Bull. Brook. Ent. Soc. 11: 46-7.

2. Grænicher, S. 1905. Some observations on the life history and habits of parasitic bees. Bull. Wis. N. H. Soc. 3: 153-67.

3. ......, 1906. A contribution to our knowledge of the visual memory of bees. Bull. Wis. N. H. Soc. 4: 138-9.

4. Robertson, C. 1899. On the flower visits of oligotropic bees. Flowers and insects XIX. Bot. Gaz. 26: 27-37.

5. . . . . . , 1899. Flower visits of oligotropic bees. Bot. Gaz. 28: 215 .

6. ......, 1924. Phenology of anthophilous insects. Flower visits of insects II. Psyche 31: 93-111.

7. Shuckard, W. E. 1866. British bees.

8. Swenk, M. F. 1914. Studies of North American bees. University Studies. Lincoln Nebr. 14: 1-36.

9. Mueller, H. 1883. Fertilisation of flowers. 

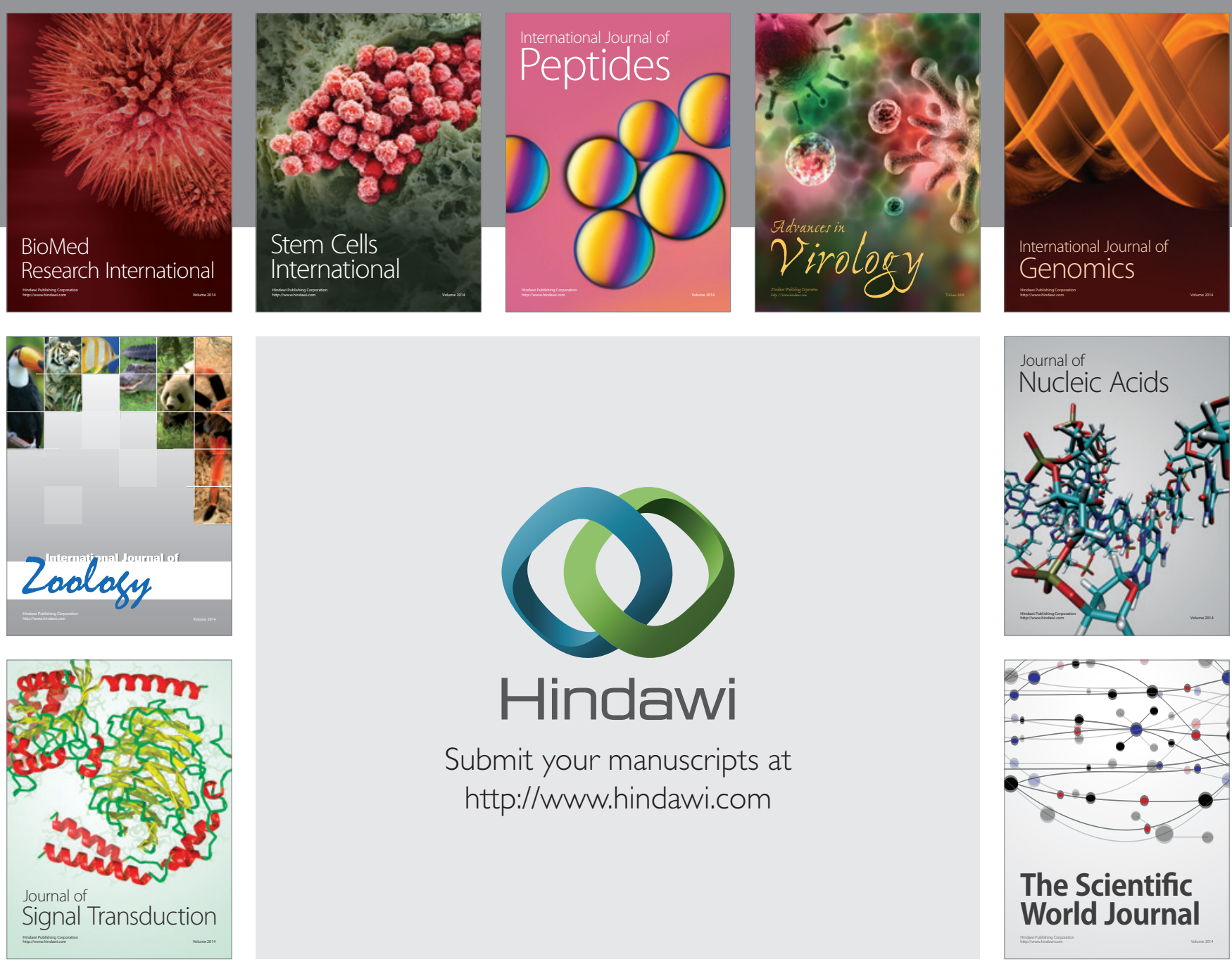

Submit your manuscripts at

http://www.hindawi.com
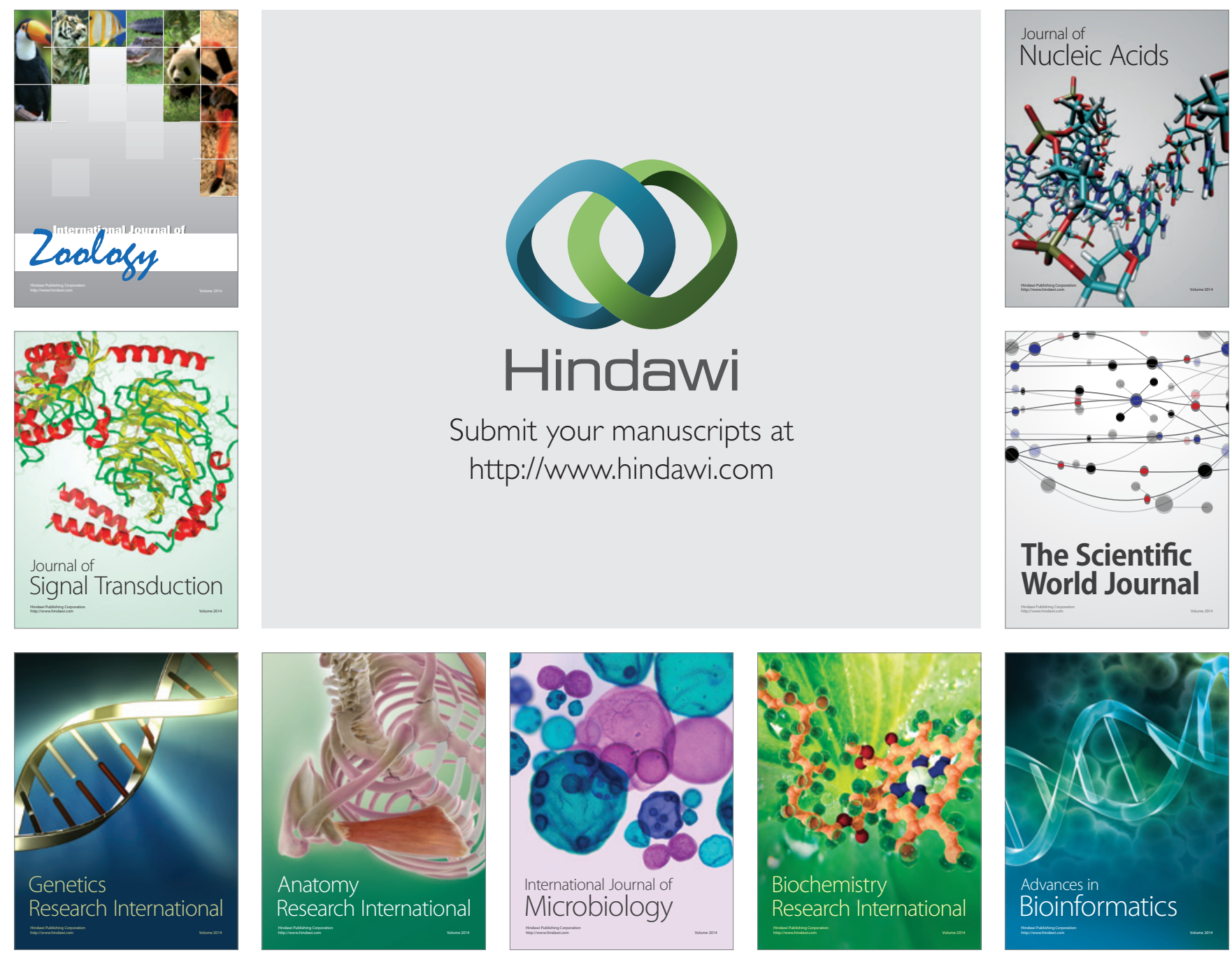

The Scientific World Journal
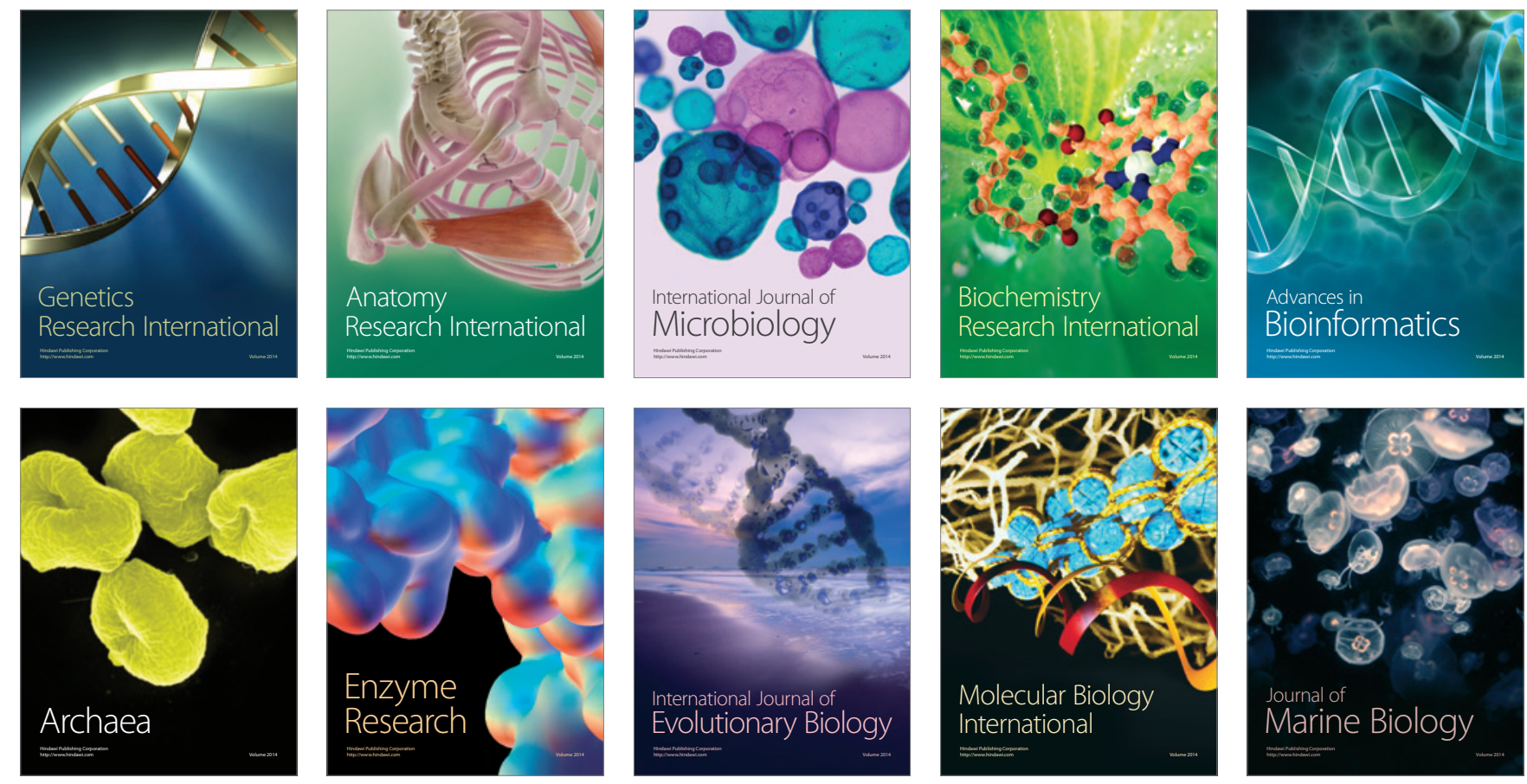